\title{
Serum $\gamma$-Glutamyl Transferase Activity in Diabetic Ketoacidosis and Non-Ketotic Hyperosmolar Coma
}

Dear Sir,

The enzyme $\gamma$-glutamyl transferase is one of the few enzymes with high diagnostic value in internal medicine [1]. Several papers have reported mild increases of serum $\gamma$-glutamyl transferase activity in patients with diabetes [2-4], although the nature of this elevation is at present obscure.

In this study, we measured the activity of serum $\gamma$-glutamyl transferase in uncontrolled diabetic patients. Thirty-one patients with uncontrolled diabetes were enrolled into this study after they or their families had given informed consent. Fifteen female and 13 male Type 1 (insulin-dependent) diabetic patients were diagnosed as being in diabetic ketoacidotic crisis. Their mean age was $31 \pm 21.3$ years (mean \pm $\mathrm{SD}$ ); four patients had mild background diabetic retinopathy and the mean duration of diabetes was $9.96 \pm 7.09$ years. Three female Type 2 (non-insulin-dependent) diabetic patients were diagnosed as suffering from non-ketotic hyperosmolar coma. Their mean age was $72.3 \pm$ 8.38 years (mean $\pm \mathrm{SD}$ ); none had any micro- or macrovascular complications and the mean duration of diabetes was 17 months. A group of 13 female and 12 male healthy volunteers served as control subjects. Their mean age was $35 \pm 17.6$ years ( \pm SD). None of the patients or control subjects had been receiving drugs known to affect serum enzyme levels, nor were they suffering from liver or pancreatic diseases or chronic alcoholism (the upper limit for the daily alcohol intake was $8 \mathrm{~g}$ for diabetic patients and $10 \mathrm{~g}$ for control subjects). In each diabetic patient serum $\gamma$-glutamyl transferase was measured within the first $24 \mathrm{~h}$ after admission and at 48 and 72 h. $\gamma$-Giutamyl transferase was assayed by a kinetic spectrophotometric method according to Szasz [5]. The results obtained were analysed according to the Student's t-test for difference between mean serum $\gamma$-glutamyl transferase in normal subjects and diabetic patients and Student's t-test for paired data for difference of $\gamma$-glutamyl transferase activity on three consecutive days after the start of treatment of ketoacidosis or non-ketotic hyperosmolar coma.

The mean serum $\gamma$-glutamyl transferase values of uncontrolled diabetic patients and healthy volunteers are shown in Table 1 . There was

Table 1. Serum $\gamma$-glutamyl transferase activity in patients with diabetic ketoacidosis, non-ketotic hyperosmolar coma and in healthy volunteers

\begin{tabular}{llll}
\hline & \multicolumn{3}{l}{$\gamma$-glutamyl transferase (units/l) } \\
\cline { 2 - 4 } & Day 1 & Day 2 & Day 3 \\
\hline $\begin{array}{c}\text { Diabetic ketoacidosis } \\
(n=28)\end{array}$ & $16.36 \pm 9.05$ & $15.85 \pm 9.56$ & $17.12 \pm 9.46$ \\
$\begin{array}{c}\text { Non-ketotic hyper- } \\
\text { osmolar coma }(n=3)\end{array}$ & $17.33 \pm 2.51$ & $15.40 \pm 3.20$ & $16.78 \pm 3.07$ \\
$\begin{array}{c}\text { Healthy volunteers } \\
(n=25)\end{array}$ & $18.02 \pm 9.10$ & - & - \\
\hline
\end{tabular}

Results are expressed as mean \pm SD. Differences between means of serum $\gamma$-glutamyl transferase in all groups were not significant no significant difference between the control group and the diabetic patients. Furthermore, serum $\gamma$-glutamyl transferase activity remained unmodified in diabetic patients during three consecutive days after the onset of treatment.

Increased serum $\gamma$-glutamyl transferase activity has been reported in some diabetic patients, of which the highest elevations were present in patients who had at least one abnormal liver function test [3] or had diabetic vascular complications [4]. The results obtained by Martin et al. [6] support the hypothesis that a raised blood glucose may act as an enzyme-inducing agent, resulting in increased serum $\gamma$-glutamyl transferase activity in diabetes.

In our study, we did not observe any statistically significant difference between serum $\gamma$-glutamyl transferase activity in normal subjects and in patients with acute diabetic crises, suggesting that acute increases in blood glucose in diabetic patients do not cause $\gamma$-glutamyl transferase induction at hepatic microsomal level. We think that the overall relation of $\gamma$-glutamyl transferase activity and diabetes mellitus deserves further investigation.

Yours sincerely, J.Jiménez-Alonso, F. Pérez-Jiménez, L. Jaimez, R. Muñoz and J. A.Jiménez-Perepérez

\section{References}

1. Rosalki SB (1975) Gamma-glutamyl transpeptidase. In: Bodansky O, Latner AL (eds) Advances in clinical chemistry, Vol 17. Academic Press, New York, pp 53-107

2. Boone DJ, Routh JI, Schrantz R (1974) $\gamma$-Glutamyl transpeptidase and 5'-nucleotidase. Comparison as diagnostics for hepatic disease. Am J Clin Pathol 61: 321-327

3. Goldbarg JA, Pineda EP, Smith EE, Friedman OM, Rutenburg AM (1963) A method for the colorimetric determination of $\gamma$-glutamyl transpeptidase in human serum; enzymatic activity in health and disease. Gastroenterology 44: 127-133

4. Jacobs WLW (1972) $\gamma$-Glutamyl transpeptidase in diseases of the liver, cardiovascular system and diabetes mellitus. Clin Chim Acta 38: $419-434$

5. Szasz G (1969) Kinetic photometric method for serum gamma-glutamyl transpeptidase. Clin Chem 15:124-136

6. Martin JV, Haghe RV, Martin PJ, Cullen DR, Goldberg DM (1976) The association between serum triglycerides and gamma-glutamyl transpeptidase activity in diabetes mellitus. Clin Biochem 9: 208-211

Dr. J.Jiménez-Alonso

Departamento de Medicina Interna

Ciudad Sanitaria "Reina Sofia"

Córdoba, Spain 